\title{
A COMPLEXA DEFINIÇÃO DE ATO TERRORISTA COMO CRIME CONTRA A HUMANIDADE
}

\section{THE COMPLEX DEFINITION OF TERRORIST ACT AS A CRIME AGAINST HUMANITY}

\author{
Juliette Robichez \\ Centro Universitário Jorge Amado - Unijorge - (Salvador, BA, Brasil) \\ Luíza Moura Costa Spínola \\ Universidade Católica do Salvador - UCSal - (Salvador, BA, Brasil) \\ Recebimento: 20 out. 2019 \\ Aceitação: 15 maio 2020
}

\begin{abstract}
Como citar este artigo / How to cite this article (informe a data atual de acesso / inform the current date of access):
ROBICHEZ, Juliette; SPÍNOLA, Luíza Moura Costa. A complexa definição de ato terrorista como crime contra a humanidade. Revista da Faculdade de Direito UFPR, Curitiba, v. 65, n. 2, p. 149-176, maio/ago. 2020. ISSN 22367284. Disponível em: https://revistas.ufpr.br/direito/article/view/69797. Acesso em: 31 ago. 2020. DOI: http://dx.doi.org/10.5380/rfdufpr.v65i2.69797.
\end{abstract}

\section{RESUMO}

Os atos de terrorismo constituem um fenômeno global que tem impacto nas questões de paz e de segurança, nacional e internacionalmente. A criação do Tribunal Penal Internacional se deve aos esforços de diversos Estados para instituir um órgão capaz de julgar crimes de elevada repercussão internacional. Quanto ao crime contra a humanidade, há uma discussão acerca de quais poderiam ser os sujeitos ativos: se apenas pessoas vinculadas a um Estado ou se membros de entidades não estatais, como grupos terroristas. Conclui-se que certos grupos terroristas, autores de atentados de grandes proporções e que apresentem alto grau de organização, podem ter seus membros considerados sujeitos ativos de crimes contra a humanidade e, por conseguinte, essas pessoas podem ser julgadas pelo Tribunal Penal Internacional. Nessa perspectiva, foi realizada uma pesquisa qualitativa, bibliográfica, documental e jurisprudencial, com enfoque na literatura brasileira e estrangeira. Preliminarmente, contudo, foi conduzida uma análise crítica, baseada em procedimentos metodológicos comparativos e históricos para entender a dificuldade de se definir o terrorismo, passo indispensável para criar uma norma internacional consensual.

\section{PALAVRAS-CHAVE}

Direito penal internacional. Tribunal Penal Internacional. Crimes contra a humanidade. Terrorismo.

\begin{abstract}
Terrorism acts constitute a global phenomenon that has an impact on peace and security issues, nationally and internationally. The creation of the International Criminal Court is a consequence of several states' effort to establish a court capable of prosecuting general international repercussion crimes. About the crime against humanity, there is a discussion about what the active subjects could be: if only people linked to a state or if members of non-state entities, such as terrorist groups. It is concluded that certain terrorist groups, perpetrators of large-scale and highly organized attacks, may be considered active subjects of crimes against humanity, and that the International Criminal Court
\end{abstract}


can try them. From this perspective, a qualitative, bibliographical, documentary and jurisprudential research was conducted, focusing on Brazilian and foreign literature. Preliminarily, however, a critical analysis was conducted, based on comparative and historical methodological procedures, to understand the difficulty of defining terrorism, an indispensable step in creating a consensual international norm.

\section{KEYWORDS}

International criminal law. International Criminal Court. Crimes against humanity. Terrorism.

\section{INTRODUÇÃO}

No período contemporâneo, diversos conflitos armados surgiram, obrigando a sociedade internacional a adequar seu arsenal normativo à realidade atual: a guerra tradicional, confronto direto e declarado entre dois Estados inimigos, foi substituída por novas formas de conflitos armados, tornando o Direito de Haia, fomentado principalmente no século XIX, obsoleto. Assim, os atos terroristas, cometidos por atores não estatais, fenômeno que sempre existiu na história da humanidade ${ }^{1}$, vêm ocorrendo em uma amplitude sem precedente no período contemporâneo, acentuada por uma difusão pelos meios de comunicação, o informático em particular.

O terrorismo influencia políticas exteriores e constitui uma das maiores preocupações das Estados, como notou-se nos ataques do grupo Al Qaeda, em Nova Iorque e em Washington, em 11 de setembro de 2001. O atentado às Torres Gêmeas simboliza a “onda religiosa” de terrorismo em grande escala que sucedeu às três ondas anteriores da evolução do terrorismo nos tempos modernos, tais como listadas por David Rapaport (2002)², que ameaçam a "paz e a segurança internacionais" (Carta da ONU). Essa quarta onda, que o referido autor britânico data de 1979, ano da Revolução Islâmica no Irã, da invasão do Afeganistão pela União Soviética e da ocupação da Grande Mesquita de Мeca, afeta todos os continentes e povos: vários grupos religiosos muçulmanos, mas também judeus, sikhs e cristãos, praticam o terrorismo em nome das suas ideologias. Uma das particularidades do modus operandi dessa onda é a sistematização dos atentados suicidas.

O banco de dados The Global Terrorism Database (GTD), elaborado pelo National Consortium for the Study of Terrorism and Responses to Terrorism (START) e sediado na Universidade de Maryland, nos Estados Unidos, contabiliza, entre 1970 e 2017, mais de 180.000

1 Por exemplo, os assassinos que, no final do século XI, no Oriente Médio, mataram governadores, líderes políticos e militares para criar alianças.

2 David Rapaport (2002) distingue quatro ondas, nos tempos modernos, na evolução do terrorismo. A primeira onda engloba os atos violentos perpetrados pelos anarquistas do mundo inteiro nas décadas de 1870 e 1880, seguida pela "onda anti-colonialista”, a partir dos anos de 1920. A terceira, chamada do "terrorismo vermelho" ou "onda da nova esquerda”, começou nos anos de 1960. Finalmente, a quarta onda é a atual - “onda religiosa”. 
eventos terroristas domésticos e transnacionais que mataram, feriram gravemente, deslocaram e traumatizaram pessoas no mundo inteiro ${ }^{3}$. Todavia, o terrorismo não assola todas as regiões do mundo igualmente: o Departamento de Estado dos Estados Unidos relata um aumento do número de atos terroristas no solo americano, mas incomparável com os atos praticados no mundo muçulmano, por exemplo (UNITED STATES DEPARTMENT OF STATE, 2018).

Os países mais afetados são, segundo as estatísticas já mencionadas, o Afeganistão, o Iraque, a Síria, o Paquistão, a Nigéria e a Rússia. Observando-se a União Europeia, conforme a Europol (agência da manutenção da ordem na organização regional), o número de pessoas atingidas por ataques terroristas não ultrapassa centenas de vítimas por ano (EUROPOL, 2019) ${ }^{4}$. Já no caso brasileiro, embora o País não tenha apresentado nenhum incidente terrorista até hoje, a internacionalização das atividades de terror teve impacto na organização, por exemplo, dos megaeventos desportivos (Jogos Olímpicos e Copa do Mundo) e refletiu na adoção de uma nova legislação. Em resumo: o terrorismo constitui hoje um fenômeno mundial que aflige muitos Estados e que requer uma resposta também global. Contudo, as iniciativas de conceituação e tipificação enfrentam um obstáculo: não existe consenso quanto à definição de terrorismo.

O novo desafio do Direito Internacional, para responder às expectativas da população e lutar de maneira eficaz contra os conflitos armados nas relações internacionais, é oferecer novas normas aptas a abranger, em particular, esses atos violentos que visam a população civil com o objetivo de aterrorizá-la. Há duas frentes complementares para proibir, ou pelos menos inibir, o uso da força nas relações internacionais: uma privilegia a prevenção, e a outra, a repressão. A criação em 1945 do Conselho de Segurança da ONU, órgão dotado de poderes de sanção, é uma das medidas profiláticas mais representativas. O surgimento da justiça penal internacional foi outra diligência para concretizar o Direito Humanitário e condenar os responsáveis por crimes internacionais.

Após a Segunda Guerra Mundial, em razão do sentimento de repulsa pelos atos cometidos pelos nazistas, foram estabelecidos os Tribunais Militares Internacionais de Nuremberg e Tóquio, órgãos ad hoc criados para julgar os crimes de lesa-humanidade praticados durante esse período pela Alemanha e pelo Japão, respectivamente. Já na década de 1990, houve a segunda fase dos tribunais internacionais, com a criação dos Tribunais Penais Internacionais para a ex-Iugoslávia e para Ruanda, por meio de resoluções do Conselho de Segurança das Nações Unidas, para julgar crimes cometidos

3 Disponível em: https://bit.ly/2ElZlqw. Acesso em: 17 jul. 2019.

4 Em 2006, segundo uma sondagem de opinião, Eurobaromètre, 40\% dos neerlandeses consideraram o terrorismo como um dos problemas mais importantes que o país estava enfrentando. À época, a Holanda não tinha sofrido nenhum ataque terrorista, mas os neerlandeses estavam mais assustados que os espanhóis ou britânicos, que tinham acabado de sofrer violências terríveis em Madri (200 mortos) e em Londres (mais de 50 mortos). 
nos respectivos países. A Justiça Penal Internacional foi consolidada pela implantação de uma jurisdição permanente, o Tribunal Penal Internacional (TPI), por meio do Estatuto de Roma, assinado em 1998. Sua jurisdição tem caráter complementar, ou seja, só pode atuar em casos em que o Estado seja incapaz ou não tenha condições de julgar os responsáveis. De acordo com o art. $5^{\circ}$ desse estatuto, o TPI é competente para julgar casos de genocídio, crimes de guerra, de agressão e contra a humanidade.

O crime contra a humanidade está previsto no art. $7^{\circ}$ do Estatuto de Roma. É conceituado como qualquer um dos atos previstos nas alíneas do $\S 1^{\circ}$ do referido artigo, como, por exemplo, homicídio, tortura e violência sexual, quando cometidos "no quadro de um ataque, generalizado ou sistemático, contra qualquer população civil, havendo conhecimento desse ataque”. Já no $\S 2^{\circ}$ é explicado que o conceito de “ataque contra uma população civil” seria qualquer conduta que envolva a prática múltipla dos atos citados no $\S 1^{\circ}$ contra uma população civil, conforme a política de um Estado ou de uma organização de praticar esses atos ou com o objetivo de prosseguir com essa política.

O termo “organização” utilizado neste artigo leva ao seguinte questionamento: —É possível que uma organização não vinculada ao Estado, mais especificamente uma organização terrorista, seja sujeito ativo de um crime contra a humanidade?

Uma das primeiras questões que se enfrenta ao tratar desse assunto é o fato de que não há um conceito universal do que seria terrorismo, quanto mais do que seria uma organização terrorista. No entanto, trata-se de um tema atual discutido em diversos países. Grupos terroristas como o Estado Islâmico (EI; ISIS no acrônimo inglês ou Daech, no árabe influenciado pelo inglês), a Al Qaeda e o Boko Haram, praticam rotineiramente atos que transcendem as fronteiras dos Estados e que poderiam se amoldar às condutas tipificadas no $\S 1^{\circ}$ do art. $7^{\circ}$ do Estatuto de Roma.

Portanto, faz-se relevante analisar esse tema para verificar se os atos cometidos por um grupo terrorista podem ser classificados como crimes contra a humanidade e, principalmente, se integrantes de um grupo terrorista poderiam ser considerados autores de um crime como esse. Na hipótese de uma resposta positiva para essa questão, poderiam ser julgados pelo TPI, se não houvesse interesse ou condições por parte do Estado responsável por processar e julgar tais delitos. Nesta perspectiva, realizou-se uma pesquisa qualitativa, bibliográfica, documental e jurisprudencial, com foco na literatura brasileira e estrangeira, sendo o método predominante na elaboração desse trabalho o de revisão bibliográfica. Contudo, preliminarmente, será conduzida uma análise crítica, baseada em procedimentos metodológicos comparativos e históricos, para entender a dificuldade de se definir o 
terrorismo, etapa necessária para alcançar uma cooperação internacional efetiva na luta contra os atentados.

\section{CONCEITUAÇÃO E TIPIFICAÇÃO DO TERRORISMO}

A expressão “terrorismo” surgiu na época da Revolução Francesa, a partir do período que ficou conhecido como Terror (JAPIASSÚ, 2009, p. 52). De acordo com as lições de Elisa Maluf (2016, p. 21), o desenvolvimento da sociedade ao longo do século XX motivou o processo de sofisticação das técnicas dos acusados de terrorismo. As vítimas desses atos não eram mais escolhidas entre as pessoas notórias e estadistas, mas entre indivíduos comuns, e o terrorismo se tornou uma estratégia bastante utilizada por grupos nacionalistas. Já na década de 1990, houve um processo de maior organização dos movimentos voltados para o jihad, com o objetivo de combater os considerados “pecadores”.

Esses eventos incentivaram novas medidas adotadas por organizações multilaterais, como a Organização das Nações Unidas (ONU), a União Europeia (EU) e a Organização dos Estados Americanos (OEA), para confrontar a ameaça terrorista. A ONU direcionou a maior parte dos países a assumir certas leis e reforçar seus respectivos aparatos militares para lidar com o terrorismo. Porém, autores como Almeida e Bazzano (2014, p. 75) e Bruce (2013) ressaltaram que a discussão ainda está distante de chegar a um consenso.

Quais são as razões da dificuldade para formular uma definição de terrorismo universalmente aceita? Alex Schmid (2004), um dos principais pesquisadores na seara dos estudos sobre terrorismo e contraterrorismo, elenca quatro motivos: $i$ ) o terrorismo é um conceito contestado, cujos sinais sociais, legais e políticas divergem frequentemente ${ }^{5}$; ii) a questão relativa à definição é ligada à legitimação e à criminalização de alguns grupos ${ }^{6}$; iii) existem vários tipos de terrorismo, cada

5 Um exemplo: como o argentino Ernesto Guevara, Yasser Arafat, ex-líder da Organização para a Libertação da Palestina (OLP), foi considerado um terrorista segundo as autoridades norte-americanas e um combatente para a liberdade, detentor do Prêmio Nobel da Paz, segundo os defensores do povo palestino oprimido.

6 Vale lembrar as pressões políticas para incluir o Hezbollah, partido político e grupo militante xiita no Líbano, na lista das organizações terroristas da União Europeia (UE). Finalmente, em 2013, a UE colocou a ala militar do Hezbollah na sua lista das organizações estigmatizadas. Ademais, governos autoritários têm tendência a alegar a luta contra o terrorismo para justificar a adoção de leis de exceção, o uso da tortura, a violação flagrante dos direitos humanos para implantar medidas de repressão e perseguição dos oponentes políticos. 
um apresentando uma forma ou manifestações diferentes ${ }^{7}$; iv) o vocábulo sofreu mudanças quanto ao seu significado em 200 anos de existência ${ }^{8}$.

Alex Schmid e Albert Jongman (1988, p. 5-6) analisaram as tentativas acadêmicas de chegar a uma definição de terrorismo. Por meio da verificação das respostas ao questionário encaminhado aos principais pesquisadores do tema sobre a definição de terrorismo, eles destacaram 22 componentes elementares, atualizados no ano de 2010 e seguintes ${ }^{9}$.

Walter Laqueur, em sua obra Terrorism, publicada em 1977, afirma que, para evitar o risco de lidar com “controvérsias sem fim”, foi adotada uma definição ampla do fenômeno: “Terrorismo é o uso ilegítimo da força para atingir um objetivo político, visando pessoas inocentes” (LAQUEUR, 1977, p. 179, tradução nossa $)^{10}$. Segundo o historiador, o ato inclui violência ou ameaça do uso da violência, componente que constitui a única característica comum a todas as definições do conceito em tela. Todavia, muitas espécies delitivas já presumem o emprego de violência, de modo que este não pode ser um aspecto determinante para distinguir o terrorismo (MALUF, 2016, p. 23). Da mesma forma, segundo os acadêmicos, o caráter político do objetivo perseguido pelos terroristas não é sempre um componente relevante. Por exemplo, o diretor do centro de pesquisa sobre o extremismo da Universidade de Oslo, Tore Bjørgo (2005, p. 2), alerta que o terrorismo é antes de tudo um “conjunto de métodos de combate e não de ideologia ou movimento identificável”.

Fernando Reinares (2005, p. 2) refinou o conceito ao considerar que um ato de violência é considerado terrorista se o impacto psíquico provocado em uma sociedade ou em algum segmento dela, em termos de ansiedade e medo, excede suas consequências materiais, ou seja, os danos físicos causados intencionalmente a pessoas ou coisas. Aqueles que instigam ou executam o terrorismo pretendem, assim, condicionar as atitudes e os comportamentos de governantes ou governados.

Caso se considere o terrorismo como ato voltado para criar um sentimento social de terror, a natureza do seu discurso se revela como uma experiência subjetiva, característica própria da manipulação de sentimentos (CALLEGARI et al., 2016, p. 33). Dessa maneira, é necessário

\footnotetext{
A Europol distingue cinco grupos diferentes, em função de sua ideologia: "terrorismo de inspiração religiosa”; "terrorismo separatista e etno-nacionalista"; "grupos anarquistas e de extrema-esquerda"; "grupos de extrema direita" e "terroristas individuais".

8 O assassinato de um chefe de Estado norte-americano atualmente seria qualificado como ato terrorista, o que não foi o caso em 1901, na mídia nacional e internacional, quando o presidente americano McKinley foi vítima, em Nova Iorque, de tiros pelo anarquista Leon Czolgosz.

9 Dentre os referidos elementos, destacam-se o uso da força e da violência, o objetivo político, o medo e o terror, os efeitos psicológicos e a antecipação das reações, as vítimas, ação planejada e sistematizada, uso de método de combate, de estratégia e de tática, coerção, aspecto público, aleatoriedade, indiscriminação do alvo, movimentos e organizações como perpetradores, aspecto simbólico, imprevisibilidade e incalculabilidade na ocorrência da violência, natureza secreta e clandestina, caráter serial e repetitivo da campanha de violência. Cf. SCHMID, 2011, 2013.

10 No original: "Terrorism is the illegitimate use of force to achieve a political objective by targeting innocent people".
} 
interpretar o terrorismo como uma estratégia de comunicação, ou seja, a essência do terrorismo se percebe não no dano material, que pode ser identificado e difundido de maneira instantânea, mas na mensagem que complementa o ato e que se difunde com a divulgação dos danos.

Existe, com efeito, uma relação estreita entre a mídia e o terrorismo. Assim, como o principal aspecto apresentado pelo terrorismo é a utilização do discurso do medo, é necessária a verificação desse elemento para sua configuração. Trata-se de um de seus aspectos mais notáveis, pois não se pode considerar a instrumentalização de certas vítimas por um grupo, com o objetivo de coagir o Estado a tomar determinada decisão política, como uma conduta terrorista se o ato em questão não tiver importância a ponto de provocar temor na sociedade.

Como desdobramento desse aspecto comunicacional, configura-se a instrumentalização das vítimas ${ }^{11}$. Para que o discurso do terrorismo atinja a proporção desejada por seus autores, é preciso que seus efeitos não se restrinjam às vítimas diretas de seus danos. A disseminação do sentimento de terror é alcançada quando as repercussões se estendem para além das pessoas efetivamente atacadas. Dessa forma, entende-se que é da natureza do terrorismo um caráter aleatório na identificação de suas vítimas.

Carlos Japiassú (2009, p. 57) sintetiza os três elementos essenciais necessários para definir um ato terrorista: i) deve constituir uma infração penal na maior parte dos ordenamentos jurídicos nacionais, como homicídio, extorsão, tomada de reféns e tortura; ii) deve ter como finalidade propagar o terror, que significa medo e intimidação por meio de ação violenta ou ameaça; iii) deve ser dirigido contra um Estado ou grupos particulares de pessoas, mas não pode ser motivado por razões particulares.

Além do elemento comunicacional e do caráter indiscriminado das vítimas, o terrorismo é qualificado pela possibilidade de reiteração dos atos. Callegari et al. (2016, p. 38) ensinam que o que torna de tamanha magnitude o temor do terrorismo é a possibilidade de repetição de um ato já consumado e que, devido à indiferenciação dos seus efeitos, tais atos possam atingir qualquer pessoa. Se inexistente a possibilidade de reiterar o ato terrorista os efeitos de terror visados não serão produzidos, ocorrendo apenas um sentimento de comoção por parte da sociedade. Ainda que somente uma conduta tenha sido praticada, sua classificação como terrorista é viável. O sentimento de pânico gerado não depende da pluralidade de atos concretos, mas de uma presunção de repetição do ato que

11 Sobre o tema indica-se a leitura, por exemplo, de Al-Qaida par l’image. La prophétie du martyre, livro do cientista político Abdelasiem El Difraoui (2013), que analisa e decifra a linguagem audiovisual de um grupo terrorista na sua propaganda. 
possa ser verificada de maneira objetiva. Mesmo que a perspectiva não se concretize, já se mostra como meio idôneo para o alcance dos objetivos desejados pelos terroristas.

É necessário ainda distinguir as noções de terrorista e freedom fighters. Maluf (2016, p. 23) explica que a expressão de língua inglesa se refere ao combatente que luta por libertação nacional e autodeterminação de um povo. Muitos Estados ainda divergem quanto à necessidade de excetuar os atos cometidos com objetivo de autodeterminação de um povo. Nessa situação, os autores dos atos violentos costumam atacar autoridades e instituições que representam em si a tirania e o abuso de autoridade que aqueles desejam combater ou aniquilar. Assim, na luta de libertação nacional, os ataques não são direcionados contra a sociedade, ou seja, não atingem vítimas indiscriminadas; pelo contrário, busca-se o apoio social para a causa considerada legítima pelos rebeldes. Entretanto, não é viável falar em legitimidade na prática de atos terroristas, pois o terrorismo demanda uma violência desproporcional contra a própria sociedade, a qual se pretende intimidar.

Quanto às distinções entre guerrilha e terrorismo, primeiramente é necessário esclarecer que a guerrilha não se confunde com a resistência armada, nem mesmo com o terrorismo (LAQUEUR, 1977; MALUF, 2016, p. 27). Os guerrilheiros buscam uma espécie de controle ou soberania sobre uma área geograficamente definida e sobre uma população, de modo que teriam o intuito de avançar sobre o território do inimigo. Trata-se de um conflito difuso, de modo que os guerrilheiros preferem lutar de forma prolongada, evitando confrontos físicos com o inimigo, e costumam voltar os ataques contra alvos militares e buscar o apoio da população civil.

Já os terroristas procuram esconder-se das forças inimigas, para auxiliar a compor o cenário de medo e ameaça por meio da imprevisibilidade. Contudo, a proclamação, em junho de 2014, da instituição de um califado, um Protoestado islâmico, em territórios controlados no Iraque e na Síria, pela organização militar e política de ideologia salafista, Daech, tornou a tentativa de diferenciar o terrorismo da guerrilha ainda mais difícil. Essas discrepâncias doutrinárias na conceituação do fenômeno terrorista se refletem nas tentativas normativas de tipificação do crime.

\subsection{DIVERGÊNCIAS NORMATIVAS}

A unificação do conceito e a tipificação de atos terroristas são necessárias para promover a cooperação entre os Estados na persecução penal do terrorismo. As iniciativas de regulamentação são de cunho internacional e nacional. 


\subsubsection{Iniciativas internacionais}

As discussões entre Estados sobre o tema foram intensificadas em virtude do assassinato do rei Alexandre da Iugoslávia e do Ministro dos Negócios Estrangeiros da França, Louis Barthou, por terroristas macedônios e croatas, em Marselha, no ano de 1934. Durante uma reunião da Liga das Nações foi adotado o primeiro instrumento jurídico que considerou o terrorismo como crime internacional: a Convenção para a Prevenção e Punição do Terrorismo, assinada em 16 de novembro de 1937 por somente 21 Estados, mas que nunca entrou em vigor. O art. $1^{\circ}$ da convenção definiu “atos de terrorismo" como "aqueles dirigidos contra um Estado e com a finalidade ou natureza de provocar o terror em certas pessoas, grupos de pessoas ou ao público em geral” e o art. $4^{\circ}$ convidou os Estados signatários a criarem infração específica nas suas respectivas legislações.

O tema foi pouco discutido na comunidade internacional por algum tempo. Apenas nas décadas de 1960 e 1970 é que foram elaboradas algumas convenções nesse sentido, como a Convenção Relativa a Infrações e a Certos Atos Ocorridos a Bordo de Aeronaves (1963), a Convenção para a Repressão da Captura Ilícita de Aeronaves (1970) e a Convenção para Repressão de Atos Ilícitos Dirigidos Contra a Segurança da Aviação Civil (1971).

A partir do ano de 1972, com o acontecimento do Massacre de Munique, surgiram mais acordos internacionais com o intuito de intensificar o combate ao terrorismo, como, por exemplo, a Convenção Internacional Contra a Prisão de Reféns (1979) e a Convenção para a Proteção Física de Materiais Nucleares (1980). Durante as décadas de 1980 e 1990, a ONU desempenhou um papel ainda mais relevante no que tange ao combate às práticas terroristas, aprovando mais algumas normas sobre o tema. A Assembleia Geral da ONU reconheceu em 1987, por meio da Resolução 42/159, que a efetividade da luta contra o terrorismo poderia ser ampliada por meio do estabelecimento de uma definição de terrorismo internacional universalmente aceita. Segundo Maluf (2016, p. 30), à época o organismo internacional não adotou medidas mais efetivas no combate ao terrorismo nem sugeriu um conceito de terrorismo.

Com a Resolução 49/60 de 1994, sobre a Declaração sobre Medidas para Eliminar o Terrorismo Internacional, a Assembleia considerou injustificáveis os atos criminosos praticados com o intuito de causar um estado de terror na sociedade em geral, em um grupo de pessoas ou de pessoas específicas, com objetivos políticos. Se por um lado um conceito genérico e abstrato de terrorismo seria capaz de se adequar às mais diversas conjunturas, por outro, torna-o um tipo penal excessivamente aberto, o que poderia levar a uma persecução penal seletiva e ineficaz. 
Houve ainda a Resolução 51/210 da Assembleia, que no ano de 1996 compôs um comitê ad hoc para tratar sobre o terrorismo, com o intuito de elaborar a minuta de diversas convenções internacionais. A Resolução 51/210 ainda realizou orientações no sentido de que a minuta em questão deveria conter as principais convenções sobre o terrorismo e descrever uma série de condutas tipificadas como crime. Por meio dos trabalhos desse comitê foram elaboradas a Convenção Internacional para Supressão de Atentados Terroristas com Bombas (1997), a Convenção Internacional sobre a Supressão do Financiamento ao Terrorismo (1999) e a Convenção Internacional para a Supressão de Atos de Terrorismo Nuclear (2005).

Depois do atentado às torres gêmeas do World Trade Center, a atividade legislativa internacional para promover convenções relativas ao assunto foi intensificada, mas ainda não há consenso em relação a um conceito universalmente válido para o terrorismo.

Conforme as lições de Bechara (2014, p. 382), a importância de delimitar um conceito de terrorismo nos tratados internacionais se deve ao fato de que a cooperação jurídica se processa de acordo com os critérios e modelos do Direito Internacional, o que afasta uma leitura casuísta segundo a legislação de cada Estado envolvido. Isso porque o fundamento que explica a assistência mútua e o espírito de cooperação é a confiança entre os Estados ou entre os Estados e os organismos internacionais, como a ONU, a fomentar o esforço de solidariedade mútuo, construído a partir de bases seguras. Assim, concorda-se com o autor ao considerar a cooperação jurídica internacional como instrumento de estímulo e garantia da concretização de direitos que assume um papel de intensa relevância quanto à prevenção e repressão ao terrorismo, cujas práticas causam graves violações aos direitos humanos, conforme sempre ressaltado nas convenções internacionais sobre o assunto.

Todos os documentos já mencionados fazem parte de uma estratégia global das Nações Unidas. O princípio basilar de tal política é a cooperação nas obrigações assumidas de acordo com o Direito Internacional para responsabilizar qualquer pessoa que apoie, auxilie, participe ou queira participar do financiamento, planejamento, preparação ou execução de atos terroristas ou que garanta proteção à pessoa que pratique tais atos. Além disso, esses documentos têm por finalidade facilitar a persecução ou extradição dos praticantes de atos terroristas conforme o Direito Internacional, especialmente as normas dos Direitos Humanos, do Direito dos Refugiados e do Direito Internacional Humanitário.

Segundo o Manual de Cooperação Jurídica Internacional para Questões Criminais Relativas ao Terrorismo, elaborado pelas Nações Unidas, é necessário proporcionar uma ação eficiente no que tange às mais importantes formas de cooperação. O manual define como princípios básicos da cooperação a criminalização dos atos de terrorismo, consoante as Resoluções do Conselho 
de Segurança das Nações Unidas, os instrumentos universais, regionais e a legislação nacional. De acordo com as Nações Unidas, o conjunto de resoluções do Conselho de Segurança é considerado fonte primária, pois sua força normativa tem origem na Carta da ONU.

São exemplos de obrigações decorrentes da cooperação jurídica internacional para combater o terrorismo: processar e extraditar as pessoas envolvidas em atos terroristas; não utilizar o argumento de que se trata de crime político para frustrar o pedido de cooperação; o uso restrito da regra da especialidade, de acordo com a qual documentos obtidos por meio de cooperação internacional não podem ser utilizados para outros motivos ou procedimento; a vedação do bis in idem, para que não ocorra mais de uma acusação pelo mesmo crime.

Além dessas obrigações, o manual estabelece que as regras mais relevantes para o desenvolvimento de uma cooperação efetiva são a promoção do desenvolvimento de contatos informais, o intercâmbio de informações de maneira direta sempre que possível e a simplificação dos procedimentos para acelerar a cooperação. Quanto à última regra, o manual acentua sua importância nos requerimentos de natureza probatória nos procedimentos de extradição e nos de transmissão de dados.

Assim, conclui-se que os documentos elaborados pelas Nações Unidas, ainda que não tenham caráter obrigatório, contêm diretrizes para auxiliar os Estados durante a tomada de decisão quanto aos procedimentos de cooperação internacional, reduzindo a complexidade e otimizando o combate ao terrorismo. Eles também podem servir de base de referência para a elaboração de normas nacionais.

\subsubsection{Iniciativas nacionais}

Nessa seção será explicado como as legislações de determinados países tratam do tema. Optou-se pela análise da legislação dos Estados Unidos devido aos ataques que o país vem sofrendo nas últimas décadas, como o mundialmente conhecido atentado às Torres Gêmeas, e porque ele tem se tornado o Estado mais comprometido em combater o terrorismo. Será examinado ainda como se trata o assunto nas legislações de países europeus, como a Espanha, a França, a Inglaterra e a Alemanha. Por fim, será tratada a legislação do Brasil sobre o assunto, com destaque para a recente Lei $n^{0} 13.260$, de 16 de março de 2016, denominada Lei Antiterrorismo ${ }^{12}$.

12 Disponível em: https://bit.ly/30TnFsP. Acesso em: 18 jul. 2019. 


\section{i) Legislação estadunidense}

É possível dividir o tratamento dado aos americanos sobre o terrorismo em duas fases: antes e depois de 11 de setembro de 2001. Na década de 1980, os Estados Unidos definiram o que seria uma atividade terrorista por meio do Anti-terrorism Act. Segundo essa norma, seria terrorista qualquer “organização, apoio ou participação em um ato de violência arbitrário ou indiscriminado com extrema indiferença ao risco de causar morte ou lesões corporais a um indivíduo que não esteja tomando parte nas hostilidades armadas”. Apesar de esse ato normativo apresentar uma definição jurídica de terrorismo, o país ainda não demonstrava uma grande preocupação quanto ao assunto, que parecia uma realidade afastada da sociedade estadunidense, conforme explica Maluf (2016, p. 33).

Contudo, a conjuntura mudou com o atentado às torres gêmeas do complexo empresarial do World Trade Center realizado em 11 de setembro de 2001, no qual morreram mais de 2.700 pessoas, outras 189 no ataque ao Pentágono e mais 45 na Pensilvânia (ESSADO, 2014, p. 136). A partir desse episódio, que marcou profundamente a população mundial, teve início a chamada "guerra contra o terror”, causando mudanças profundas no Direito Penal e Processual Penal dos Estados Unidos (ALMEIDA; BAZZANO, 2014, p. 157). Apenas dois dias depois dos ataques, o então presidente Bush decretou estado de emergência nacional em caráter retroativo com base no National Emergencies Act. A chamada Declaration of National Emergency by Reason of Certain Terrorist Attacks foi prorrogada até setembro de 2005. Inicialmente, os ataques foram considerados crimes de guerra provenientes de agressores estrangeiros, demonstrando a posição estadunidense sobre a situação. A autorização para uso de força militar foi aprovada em 18 de setembro de 2001. Seis dias depois, foi adotada ordem executiva sobre o financiamento terrorista, por meio da qual se conseguiu bloquear bens de 27 indivíduos e organizações terroristas vinculados à Al Qaeda.

Ainda no ano de 2011 foi realizada, também sem debate na sociedade e no Congresso, a edição do USA Patriot Act (Lei Patriota, em tradução livre para o português). A Lei Patriota, promulgada em 26 de outubro, trouxe mais definições para atos terroristas e previu punições para o financiamento de tais atos. Em 13 de novembro de 2001, o presidente Bush decretou ordem presidencial com o intuito de estabelecer tribunais militares de exceção para julgar estrangeiros suspeitos de participar de atos terroristas ou colocar em risco a segurança nacional. A Lei Patriota é bastante extensa e complexa, segundo destaca Essado (2014, p. 138). Seu conteúdo modificou quinze leis federais. O princípio basilar dessa lei é a proteção da segurança nacional, introduzindo mudanças profundas nas estruturas nacionais.

Como exemplo dessas alterações é possível mencionar a ampliação dos poderes do Federal Bureau of Investigation (FBI), para realizar interceptações eletrônicas e para prender suspeitos de 
terrorismo. De modo geral, o complexo normativo adotado sob influência de emoção e de maneira precipitada constitui uma violação flagrante dos direitos fundamentais consagrados pelos instrumentos internacionais e pela constituição estadunidense. A Suprema Corte e as cortes locais julgaram anticonstitucionais a maioria das medidas adotadas pelo Poder Executivo ${ }^{13}$.

A Lei Patriota estabeleceu o conceito de terrorismo nacional, que seriam atos perigosos para a vida humana, segundo o Direito Penal dos Estados Unidos ou de qualquer Estado, praticados dentro da jurisdição territorial dos Estados Unidos e que tenham como finalidade intimidar ou coagir a população civil, influenciar a política do governo, por meio de intimidação ou coerção, e incidir sobre as ações do governo mediante destruição em massa, homicídios e sequestros.

Outras condutas que também foram consideradas terroristas por essa norma foram os atos violentos contra transportes públicos de massa, como incêndios dolosos e a introdução de substâncias químicas ou biológicas com o objetivo de colocar em risco a vida humana. Outras modalidades criminosas seriam a conduta de dar proteção a terroristas e o auxílio material a terroristas.

As definiç̧̃̃es apresentadas pela legislação estadunidense referem-se a condutas vagas e conceitos abrangentes de terrorismo, permitindo manobras políticas para a acusação e prisão de várias pessoas que as autoridades norte-americanas julguem suspeitas de terrorismo. As violações flagrantes do direito internacional e do direito constitucional americano foram amplamente denunciadas pelos defensores dos direitos humanos e pela própria Suprema Corte norte-americana (MASTOR, 2008).

ii) Legislações europeias

Nesta subseção serão tratadas as normas internas de alguns dos países europeus que mais têm sofrido ataques terroristas nos últimos tempos.

Segundo Tangerino (2014, p. 273), a Alemanha manifesta preocupação concreta com o terrorismo desde a década de 1970, em virtude das atividades da Fração do Exército Vermelho, organização guerrilheira de extrema-esquerda. No ano de 1986, a Lei de Combate ao Terrorismo alterou alguns conceitos jurídicos, mas apenas após o ataque de 11 de setembro de 2001 foram verificadas mudanças mais profundas sobre o assunto, especialmente a criação do art. 129-B do Código Penal, que versa sobre terrorismo internacional. Contudo, a ordem jurídica alemã não conceituou o terrorismo. Os artigos criados em 2009, que versam sobre os delitos violentos graves

13 Por exemplo, a Suprema Corte reafirmou em 2004, em três casos sobre detentos da prisão de Guantánamo, os princípios elementares do due process ao definir um standard mínimo de proteção dos direitos dos detentos nacionais ou estrangeiros; em 2006, a jurisdição negou a legitimidade da criação dos tribunais militares; em 2008, reiterou o direito dos prisioneiros da prisão sediada no território cubano ocupado pelos Estados Unidos de contestar sua detenção perante tribunais civis. 
que coloquem o Estado em perigo (arts. 89-A e 89-B do Código Penal), não mencionam expressamente o terrorismo. O que qualifica uma associação terrorista, nos termos da legislação alemã, é o delito ao qual ela se destina, como, por exemplo, homicídio qualificado, homicídio simples, crimes contra a humanidade, crimes de guerra, delitos contra a liberdade pessoal e lesão corporal grave. Ainda de acordo com o Código Penal alemão, as associações terroristas podem ser classificadas em três grupos penais: $i$ ) as associações criminosas na Alemanha para cometer crimes per se (art. 129-A, I); ii) as associações criminosas na Alemanha que cometam crimes contextualmente graves, previstos no art. 129-A, II, e as associações terroristas; e iii) as associações criminosas no exterior (art. 129-B).

A Espanha é um dos países europeus com uma das legislações mais abrangentes quanto ao combate ao terrorismo, conforme explica Moreno (2014, p. 230). A ação terrorista do fenômeno independentista basco se desenvolveu em todo o território nacional, a fim de alcançar seu objetivo por meio da luta armada, o que levou o país a adotar medidas legislativas para combater as práticas do Euskadi Ta Askatasuna (ETA). Por exemplo, a Constituição espanhola de 1978 incorporou diversas regras que amparavam a legislação de exceção, permitindo a suspensão de alguns direitos fundamentais em casos de terrorismo. Assim, Maluf (2016, p. 35) assevera que a legislação espanhola sobre o assunto sofreu poucas alterações, mesmo com os atentados de 11 de setembro de 2001 nos Estados Unidos e em 11 de março de 2004 em Madri, exatamente porque as normas sobre terrorismo já apresentavam diversas restrições aos direitos individuais. A noção de organização terrorista está prevista nos arts. 571 a 580 do Código Penal espanhol e se refere a bandos armados, organizações ou grupos com intuito de violar a ordem constitucional ou afetar a paz pública e ao pertencimento ou colaboração de um grupo terrorista.

Contudo, os artigos do Código Penal espanhol não explicam o que seria terrorismo de fato, somente tipificam condutas que expressam práticas terroristas. O código ainda demonstra que o legislador espanhol foi bastante rigoroso no que tange às penas. Por exemplo, a organização de grupo terrorista é punida com pena de oito a 14 anos e inabilitação para emprego ou cargo público por oito a 15 anos, de acordo com o $\S 1^{\circ}$ do art. 572. O Código Penal espanhol ainda sofreu uma modificação em seu art. 577, relativo ao terrorismo urbano, no ano 2000, que implicou maior abrangência do tipo penal. Após a alteração, também cometem o crime aqueles que colocam em risco a vida e a integridade física alheia, mesmo que não cheguem a causar o dano. Cancio Meliá (2014, p. 213) pondera que o Código Penal espanhol passou por uma reforma introduzida pela Lei Orgânica 5/2010, ampliando alguns conceitos como o de colaboração com organização terrorista, incluindo condutas 
como “capacitação, doutrinamento, adestramento ou formação" no tipo penal. Ademais, foi estabelecida a responsabilidade de pessoa jurídica por crime de financiamento ao terrorismo.

A França, por sua vez, de acordo com o Livre blanc et noir du terrorisme (PELLETIER, 2019) - relatório elaborado por uma deputada europeia com apoio da Association française des victimes du terrorisme -, é atualmente um dos países ocidentais que mais tem sido alvo de ataques terroristas desde os anos 2000. Há várias razões para isso, como, por exemplo, as operações militares francesas em países como a Síria, o Iraque (contra o Estado Islâmico) e o Mali (contra a AQMI, filial da Al Qaeda no Magrebe, e contra o Ansar Dine), visando atingir radicais islâmicos e suas relações com suas ex-colônias na África do Norte, em particular. A França é também o país europeu do qual saem mais jovens para se juntar ao Estado Islâmico: por volta de 1,8 mil franceses estariam envolvidos em movimentos jihadistas. Os autores dos últimos atentados em território francês apresentam um perfil semelhante: fracasso escolar e profissional, condenações na justiça por crimes com emprego de violência e tráfico e, muitas vezes, com radicalização ocorrida durante o período em que estavam presos (FERNANDES, 2016).

Ressalte-se que a luta contra o terrorismo já era uma prioridade da França na década de 1980. Foram os atentados da rua de Rennes, perpetrados pelo Hezbollah em Paris, que justificaram as reformas legislativas em diferentes ramos do direito. O termo “terrorismo” entrou no Código Penal e no Código de Processo Penal por meio da Lei no 86-1020, de 9 de setembro de 1986, relativa à luta contra o terrorismo. Tais normas consideram as motivações específicas dessas infrações, com o intuito de agravar a repressão, e autorizam um regime processual fortemente derrogatório ao direito comum, reforçando a fase do inquérito. O direito de execução das penas permite adaptação do atendimento penitenciário às especificidades dos autores de delitos terroristas (MENABE, 2016). Essas normas sofreram alterações e foram completadas por outras leis em 1996, logo depois da onda de atentados cometidos no solo francês durante o verão de 1995, e pela lei de 15 de novembro de 2001, em reação aos ataques de 11 de setembro de 2001 realizados nos Estados Unidos.

O Direito Penal francês não oferece uma definição propriamente dita de terrorismo. Referese a infrações existentes, algumas de direito comum, perpetradas com um objetivo terrorista. A qualificação de ato terrorista depende, assim, do motivo, que é o objeto da definição legal. Os atos de terrorismo são definidos no art. 421-1 do Código Penal como aqueles cometidos intencionalmente, por meio de ação individual ou coletiva, com o objetivo de causar dano à ordem pública por meio de intimidação ou terror.

A Lei Antiterrorismo francesa prevê, em seu art. $1^{0}$, que a autoridade administrativa pode proibir a pessoa de deixar o país se houver suspeita de que ela está envolvida em atividades terroristas. 
Trata-se de medida que não está fundada na culpabilidade da pessoa, mas no perigo que ela pode vir a representar, o que significa uma noção extremamente subjetiva. Já o art. 13 da Lei nº 2014-1353 alterou o Código de Processo Penal, permitindo a quebra de sigilo de dados informáticos em caso de suspeita de terrorismo. Como nas legislações estadunidense e espanhola, a flexibilidade da noção de terrorismo constitui uma ferramenta privilegiada, justificando certas políticas de segurança, tanto no plano nacional quanto no das relações internacionais (DUBUISSON, 2017).

Em $1^{\circ}$ de julho de 2019, a reforma da justiça (adotada pela lei de 23 de março de 2019) implantou o Parquet national antiterroriste (PNAT) em nome da “eficácia da justiça penal antiterrorista” (GOUVERNEMENT.FR, 2019) ${ }^{14}$. No início de setembro de 2019, o PNAT rejeitou a demanda de uma advogada, representando 23 famílias de vítimas dos atentados de 23 de novembro de 2015, para acrescentar à denúncia de terrorismo a de crime contra a humanidade para Salah Abdeslam, último sobrevivente dos comandos dos fuzilamentos em massa, dos atentados suicidas, explosões e uso de reféns que ocorreram no Bataclan, nas varandas de cafés em Paris e no Stade de France na cidade vizinha, Saint-Denis. O Parquet alegou que o novo rol de acusação tornaria os crimes imprescritíveis (LES ATTENTATS..., 2019).

Juristas franceses e jurisinternacionalistas apresentam tratamentos distintos sobre o assunto. Os primeiros consideram possível a qualificação, como atos terroristas (qualificação que existe no direito francês), dos ataques no Bataclan, bem como a de crimes contra a humanidade (BADIE, 2019; MOLINS, 2016). Já os estudiosos do Direito Internacional questionam a possibilidade de acolher na categoria crime contra a humanidade os atos ligados ao terrorismo, crime que não existe ainda em Direito Internacional. O debate divide, há alguns anos, pesquisadores e juristas especialistas em justiça penal, e demonstra a necessidade de redefinir esses conceitos para abranger ataques que desestabilizam inúmeros Estados.

Como nas legislações estadunidense e espanhola, a flexibilidade da noção de terrorismo constitui na França uma ferramenta privilegiada, legitimando determinadas políticas de segurança, tanto no plano nacional quanto no das relações internacionais (DUBUISSON, 2017). Essa tendência à restrição de direitos fundamentais em virtude dos recorrentes ataques terroristas se encontra também na legislação britânica.

14 Como a atividade antiterrorista tomou uma parte preponderante da atividade do Procurador de Paris, em particular depois dos atentados contra os jornalistas do Charlie Hebdo e no Bataclan, foi criada uma estrutura dedicada em tempo integral à luta contra o terrorismo, a qual é formada por uma equipe de magistrados e de funcionário especializados, com meios reforçados e que tem como missão reprimir crimes e delitos terroristas, crimes relativos à proliferação de armas de destruição em massa, crimes de guerra e crimes contra a humanidade. 
O Reino Unido, por sua vez, sofreu um atentado de grandes proporções após o 11 de setembro de 2001. Em 7 de julho de 2005, no centro de Londres, houve a explosão de quatro bombas, causando a morte de 50 pessoas e deixando mais de 700 feridos. $\mathrm{O}$ atentado foi reivindicado pela Al Qaeda. O terrorismo foi definido na Seção 1 do Terrorism Act de 2000 por meio da utilização de alguns elementos, como a ação ou ameaça contra pessoa ou propriedade, saúde, segurança pública ou sistema eletrônico, para influenciar o governo ou organização internacional ou intimidar o público com objetivos políticos, religiosos, raciais ou ideológicos, conforme explica Maluf (2016, p. 34).

O conceito abrangente de terrorismo trazido pelo ato normativo não foi alterado na legislação posterior, mas serviu como respaldo interpretativo para o Terrorism Act de 2006 e auxiliou no entendimento de demais termos relacionados a organizações terroristas que já estavam previstos no Terrorism Act de 2000.

A legislação de 2006 define algumas características inerentes aos atos terroristas (GEMAQUE, 2014, p. 169): são irracionais para a sociedade que os sofre; trata-se de recursos extremados; são aleatórios e imprevisíveis, ou seja, não seguem um padrão metodológico ou cronológico, se comparados a outras ocorrências, como acidentes de trânsito; são estatisticamente pouco significativos, mas promovem grande comoção popular; possuem ampla repercussão na mídia. É necessário destacar, contudo, que a Grã-Bretanha já possuía alguma experiência no combate ao terrorismo devido aos atos realizados, desde a década de 1960, pelo Provisional Irish Republican Army (IRA), grupo paramilitar que tinha como objetivo a independência da Irlanda do Norte.

É possível perceber que as legislações desses países descrevem o que seriam atos terroristas, mas não chegam a definir o terrorismo propriamente dito. A seguir será tratada a Lei $\mathrm{n}^{0}$ 13.260/16, que tipificou o terrorismo no Brasil.

\section{iii) Lei Antiterrorismo brasileira}

O Brasil assinou a maioria dos documentos internacionais sobre terrorismo, mostrando-se bastante favorável à cooperação no sentido de combatê-lo. O País é parte da Convenção das Nações Unidas para a Repressão do Apoderamento Ilícito de Aeronaves, da Convenção para Repressão dos Atos Ilícitos contra a Segurança da Aviação Civil, da Convenção Interamericana contra o Terrorismo e da Convenção Internacional para a Supressão do Financiamento ao Terrorismo.

O terrorismo é tutelado pelo ordenamento jurídico brasileiro desde a década de 1920, segundo leciona Japiassú (2009, p. 54). O Brasil adotou leis, em conformidade com os padrões europeus, para tratar dos casos de terrorismo anarquista, que repercutiram no País a partir dos imigrantes italianos. No período correspondente ao governo militar, entre 1964 e 1985, constata-se a 
existência tanto de atos terroristas cometidos pelos opositores da Ditadura quanto de condutas que se convencionaram chamar de "terrorismo de Estado", ou seja, atentados praticados por ordens de autoridades estatais.

O Decreto $n^{\circ}$ 4.269, de 17 de janeiro de 1921, sofreu críticas por tratar de matéria relativa ao terrorismo sem que houvesse uma definição para o termo. Houve então no Brasil, a partir desse decreto, uma série de normas tentando disciplinar a matéria, todas elas padecendo da mesma ausência de clareza em relação ao conceito de terrorismo. Com o advento da Constituição Federal de 1988, durante o período de redemocratização, ficou estabelecido (art. $4^{\circ}$, VIII, da Carta) que o Brasil se rege, nas suas relações internacionais, pelo princípio do repúdio ao terrorismo. A Constituição ainda criou um regime jurídico diferenciado para o terrorismo, conforme o art. 5, XLIII.

Antigamente, a matéria era tratada pela Lei $\mathrm{n}^{\circ}$ 7.170, de 14 de dezembro de 1983, conhecida como Lei de Segurança Nacional. Segundo o art. 20 dessa lei, estaria cometendo ato de terrorismo quem praticasse qualquer uma das seguintes condutas: devastar, saquear, extorquir, roubar, sequestrar, manter em cárcere privado, incendiar, depredar, provocar explosão, praticar atentado pessoal ou atos de terrorismo, por inconformismo político ou para obtenção de fundos destinados à manutenção de organizações políticas clandestinas ou subversivas.

Ademais, o Código Penal, em seu art. $7^{\circ}$, caput, combinado com o II, $a$, com redação dada pela Lei 7.209/1984, passou a dispor que o Brasil é competente para processar e julgar crimes que, por tratado ou convenção, o país se obrigou a reprimir, ainda que cometidos no exterior. Como o Brasil ratificou boa parte dos tratados internacionais sobre combate ao terrorismo, qualquer um que tenha cometido ato terrorista no estrangeiro e se encontrar no território brasileiro, pode ser processado e julgado no Brasil.

Atualmente, a Lei $n^{0}$ 13.260/2016, originada do Projeto de Lei da Câmara de $n^{\circ} 2016$, de 2015, de iniciativa da Presidente da República e que tramitou em regime de urgência, prevê diversos crimes relacionados ao terrorismo. A tipificação do crime está art. $2^{\circ}$, que dispõe que o terrorismo é a prática por um ou mais indivíduos dos atos previstos no artigo, por razões de xenofobia, discriminação ou preconceito de raça, cor, etnia e religião, quando cometidos com a finalidade de provocar terror social ou generalizado, expondo a perigo pessoa, patrimônio, a paz pública ou a incolumidade pública.

Conforme explicam Callegari et al. (2016, p. 91), a redação do tipo penal dessa lei segue a tendência mundial de reconhecer a mensagem de terror como elemento essencial do crime de terrorismo. Além disso, as condutas típicas que podem configurar o crime de terrorismo estão previstas no $\S 1^{\circ}$ do art. $2^{\circ}$, tratando-se de crime de várias ações. 
O caput do art. $2^{\circ}$ da Lei Antiterrorismo apresenta as motivações exigidas para se configurar um ato de terrorismo, bem como a finalidade que deve estar presente no mesmo ato. A motivação seria a circunstância que impulsiona o agente a cometer o ato, como, por exemplo, a insatisfação de um indivíduo com o número de imigrantes em seu país, que pode ser suficiente para ensejar a prática de um ato terrorista. O objetivo, por sua vez, seria o resultado almejado. No exemplo anterior, o intuito político da conduta poderia ser obrigar o Estado a mudar sua diretriz quanto à admissão de imigrantes no território nacional. No $\S 2^{\circ}$ do art. $2^{\circ}$ explica-se que o tipo penal de terrorismo não se aplica a manifestações diversas, contanto "que os objetivos e meios sejam compatíveis e adequados à sua finalidade”, assegurando assim o livre exercício do direito de manifestação. Para Callegari et al. (2016, p. 97) os bens jurídicos protegidos por esse crime seriam a paz pública e a democracia, uma vez que o objetivo do terrorismo é criar um estado de pânico na sociedade.

Em suma, o terrorismo, fenômeno violento que castiga todos os continentes, ainda não possui uma definição propriamente dita. Esse problema de semântica, que se choca com o princípio crimen nulla poena sine lege, torna ainda mais difícil a necessária repressão de atos terroristas no patamar internacional. Um dos desafios a ser enfrentado pelo Direito Penal Internacional é determinar quais hipóteses caracterizam crime de terrorismo, passível de ser julgado pelo TPI.

\section{HIPÓTESES DE CRIME DE TERRORISMO PASSÍVEL DE SER JULGADO PELO TRIBUNAL PENAL INTERNACIONAL}

Considerando o caráter supranacional do terrorismo, o assunto ganha ainda mais destaque, pois as normas penais antiterrorismo dos Estados não possuem um padrão comum, tampouco as normas internacionais são suficientes para resolver a questão de uma conceituação do que seria considerado crime de terrorismo. É necessário destacar que guerra e terrorismo são dois fenômenos distintos. Nos períodos de guerra há determinadas diretrizes que devem ser seguidas pelos Estados, como as Convenções de Genebra, que determinam a tutela de prisioneiros de guerra e o tratamento de proteção aos civis. Assim, não se pode considerar atos de guerra como semelhantes aos de terrorismo, pois os primeiros podem ser considerados juridicamente legítimos, dependendo da situação.

Conforme a definição adotada pela doutrina majoritária, descrita no primeiro capítulo, considera-se uma conduta terrorista qualquer ato violento contra pessoas inocentes com o intuito de forçar um Estado ou qualquer outro organismo internacional a seguir uma linha de conduta que, não fosse a repercussão do ato praticado, não seria adotada. Isso porque a finalidade principal de um ato 
terrorista é causar um estado de pânico na sociedade, coagindo, assim, o Estado ou organismo internacional a atuar conforme as exigências dos terroristas.

O Estatuto de Roma não tem por objetivo combater o terrorismo. Contudo, está disposto em seu art. $7^{\circ}$ que crimes contra a humanidade pode ser quaisquer dos seguintes atos, desde que realizados no âmbito de um ataque generalizado ou sistemático contra uma população civil: homicídio; extermínio; escravidão; deportação ou transferência forçada de uma população; prisão ou outra forma de privação da liberdade física grave, em violação às normas fundamentais de direito internacional; tortura; agressão sexual; perseguição de um grupo ou coletividade que possa ser identificado, por motivos políticos, raciais, nacionais, étnicos, culturais, religiosos ou de gênero; desaparecimento forçado de pessoas; crime de apartheid; outros atos desumanos de caráter semelhante, que causem intencionalmente grande sofrimento, ou afetem gravemente a integridade física ou a saúde física ou mental. O Estatuto ainda enuncia, no mesmo artigo, que por "ataque dirigido contra uma população civil” entende-se qualquer conduta que envolva a prática múltipla dos atos mencionados no $\S 1^{\circ}$ contra uma população civil, de acordo com a política de um Estado ou de uma organização de praticar esses atos ou tendo em vista a prossecução dessa política.

Dessa forma, para se configurar crime contra a humanidade, não seria necessária a atuação de uma entidade estatal, basta que estejam presentes os requisitos previstos no art. $7^{\circ}$ do Estatuto de Roma. Limitar a autoria desses crimes apenas a autoridades estatais poderia levar à ausência de julgamentos de muitos desses crimes, o que iria de encontro a um dos fundamentos da criação do TPI, que é evitar a impunidade. Organizações não estatais, como o EI e a Al Qaeda, poderiam, assim, ser consideradas autoras de crimes contra a humanidade.

Bassiouni (2011, p. 40) explica que desde o caso Kunarac, julgado pelo Tribunal Penal Internacional para a Antiga Iugoslávia, foi ressaltada a evolução da natureza dos conflitos armados, de modo que a capacidade de atores não estatais foi expandida. Passou-se a considerar, assim, que crimes contra a humanidade não são exclusivamente cometidos por Estados. Além disso, desde a Segunda Guerra Mundial aumentou a participação de organizações não estatais na prática de ataques massivos de civis em conflitos de caráter não internacional e em conflitos puramente internacionais. Em vários casos, esses ataques chegaram ao nível dos crimes cometidos contra a humanidade. Tais entidades não estatais incluem unidades paramilitares e grupos civis armados. O autor ainda esclarece que o conceito de crimes contra a humanidade não deve envolver todos os tipos de lesão à pessoa, porque o Direito Penal nacional seria aplicado nesses casos.

Há diversos episódios na história dos conflitos armados em que civis cometeram crimes dessa natureza. No conflito da ex-Iugoslávia, por exemplo, grupos paramilitares e civis armados 
cometeram a maior parte dos crimes contra a humanidade. Durante a época da guerra civil em Ruanda, civis hutus eram encorajados a cometer genocídio e outros crimes contra a humanidade contra civis tutsis e hutus moderados. No final, ambos os lados cometeram crimes internacionais. Pode-se mencionar ainda a situação da Libéria, em que civis armados, inclusive crianças-soldados, cometeram crimes de guerra.

Dessa forma, parece adequada a teoria criada por Hans-Peter Kaul (apud HOLVOET, 2013), ex-juiz do Tribunal Penal Internacional, segundo a qual a “organização” prevista no art. 7º 2, $a$ do Estatuto de Roma deve obedecer a alguns critérios, características que seriam semelhantes às de um Estado, para que seja considerada sujeito ativo de um crime contra a humanidade. Para Kaul, uma organização capaz de cometer crimes contra a humanidade deveria ser: i) uma coletividade de pessoas; ii) criada e atuante com um propósito comum; iii) por um período prolongado; iv) sujeita a um comando responsável ou dotada de certo grau de estrutura hierárquica, incluindo, ainda que mínimo, algum tipo de nível de política; v) capaz de impor essa política aos seus membros e prever sanções para eles e vi) capaz e dotada dos meios disponíveis para atacar qualquer população civil em larga escala (KAUL apud HOLVOET, 2013, p. 8).

Assim, conforme esses critérios, seria viável que um grupo terrorista como o EI fosse considerada um sujeito ativo de crimes contra a humanidade. Esse grupo jihadista preenche todos os requisitos necessários para tanto, pois é uma organização constituída há algum tempo, possui um objetivo claro e claramente possui os meios para realizar amplos ataques à população civil (NAPOLEONI, 2015).

Além do EI, é possível considerar a Al Qaeda uma organização que atende a esses requisitos, pois se trata de um grupo terrorista que, mesmo com a morte de seu líder, Osama Bin Laden, continua atuando em países como Afeganistão, Índia, Paquistão e Bangladesh. Japiassú (2009, p. 7) esclarece que, após muita discussão sobre o assunto, a maior parte da doutrina entende que, para se configurar um crime contra a humanidade, não há necessidade de nexo com um conflito armado. Dessa forma, ainda que boa parte dos atentados terroristas tenha uma ligação indireta com um conflito armado, como os ataques realizados pelo EI, essa não é uma condição inerente ao conceito de crime contra a humanidade.

A definição, no $\S 1^{\circ}$ do art. $7^{\circ}$ do Estatuto de Roma, de “ataque, generalizado ou sistemático, contra qualquer população civil” está também em conformidade com a instrumentalização das vítimas pelos terroristas. Boa parte dos ataques terroristas é direcionada à mais ampla quantidade de pessoas possível, para disseminar um maior sentimento de terror, não sendo importante a identidade das vítimas, segundo explicam Callegari et al. (2016, p. 38). Dessa maneira, a princípio, qualquer 
população civil poderia ser alvo de um atentado terrorista por parte de uma organização que tenha por objetivo obrigar um Estado ou organização internacional a seguir determinada diretriz política, que não seria adotada caso o sentimento de terror causado por esse ato não fosse disseminado em larga escala.

Como decorrência necessária da disseminação do terror, há a possibilidade de reiteração de atos, pois o que causa medo na população é a probabilidade de outro atentado ocorrer a qualquer momento. Assim, é viável considerar que um ataque terrorista possa ser considerado "sistemático", pois pode envolver uma série de condutas em um espaço de tempo variável. O EI, por exemplo, vem realizando vários atentados à França desde janeiro de 2015. Para Bassiouni (2011, p. 47), o ataque em massa pode ser “amplo ou sistemático” sem envolver as ações ou políticas de um Estado se for resultado de um conflito de um grupo, realizado de forma espontânea ou descontrolada. Os ataques em massa costumam ocorrer por meio do uso de forças paramilitares e de civis armados e quase sempre com o consentimento ou apoio expresso ou tácito do próprio Estado.

Assim, considera-se possível que um ato terrorista possa ser classificado como um crime contra a humanidade, sendo as condutas mais comuns em ambas as situações o homicídio e a tortura. É necessário destacar que o crime de homicídio difere do de extermínio. O art. $7^{\circ}$, $\S 2^{\circ}, b$, do Estatuto de Roma define extermínio como “a sujeição intencional a condições de vida, tais como a privação do acesso a alimentos ou medicamentos, com vista a causar a destruição de uma parte da população”. O homicídio, por sua vez, seria qualquer conduta que tire a vida de alguém, não sendo essas condutas exemplificadas no art. $7^{\circ}$ do estatuto. A alínea $e$ do referido parágrafo ainda esclarece que por tortura se entende o ato por meio do qual uma dor ou sofrimentos agudos, físicos ou mentais, são intencionalmente causados a uma pessoa que esteja sob a custódia ou o controle do acusado, como costuma ocorrer em casos de terrorismo.

Nos atos de terrorismo nos quais são feitos reféns é constante a ocorrência de tortura. Podem ser citados dois exemplos de casos que envolveram tais práticas durante a ação de grupos terroristas. Segundo o site do jornal britânico Daily Mail (ALMOND, 2018), os atletas israelenses feitos reféns no Massacre de Munique eram constantemente agredidos pelos terroristas, tendo inclusive seus ossos quebrados. Mais recentemente, em uma reportagem publicada pela Revista Exame sobre o cotidiano dos reféns do Estado Islâmico, foi mencionado que o jornalista norte-americano James Foley era alvo de tratamento desumano. Além de espancar o jornalista constantemente, os terroristas ainda o faziam passar por afogamentos simulados e encenavam sua execução (RUIC, 2014).

Podem ainda ser mencionados os atos praticados na Nigéria, em Camarões, no Níger e no Chade pelo grupo extremista islâmico Boko Haram. Além de realizar atos de homicídio e tortura, 
esse grupo é conhecido por ser contrário ao acesso à educação por parte das mulheres e costuma realizar o sequestro de meninas. Os integrantes desse grupo terrorista não apenas sequestram as vítimas, como também praticam com elas as condutas previstas no art. $7^{\circ}, \S 1^{\circ}$, alínea $g$, do Estatuto de Roma, como "agressão sexual, escravatura sexual, prostituição forçada, gravidez forçada, esterilização forçada ou qualquer outra forma de violência no campo sexual de gravidade comparável”. Segundo informações do periódico global El País (NARANJO, 2017), as mulheres sequestradas pelo Boko Haram são utilizadas pelos terroristas como escravas sexuais, cozinheiras e costumam ser obrigadas a se casarem com os combatentes. Além desses fins, a matéria veiculada no referido periódico menciona que tais mulheres podem até mesmo ser vendidas como mercadorias ou utilizadas como agentes suicidas em atentados terroristas.

Entretanto, é preciso lembrar que a atuação do TPI está condicionada ao reconhecimento da omissão dos poderes nacionais ou à demonstração de emprego de artifícios processuais pelas autoridades nacionais como forma de assegurar a impunidade dos responsáveis, conforme explica Zilli (2013, p. 166). Kai Ambos (2007, p. 79) destaca que, para o Direito Penal Internacional ser efetivamente aplicado, o TPI necessita da cooperação entre os Estados nacionais, o que nem sempre ocorre. Por exemplo, os crimes de guerra e contra a humanidade que estão ocorrendo na Síria ainda não foram levados ao TPI por motivos políticos: a Rússia e a China, dois dos cinco membros do Conselho de Segurança da ONU, votaram contra.

Assim, parece viável a possibilidade de o TPI julgar membros de uma organização não estatal por atos de terrorismo classificados como crimes contra a humanidade. Concorda-se com Lafuente (2015, p. 252) no sentido de que, para a configuração de um crime como esse, não deve ser necessário que os atos sejam cometidos por representantes de um Estado, pois isso poderia favorecer a impunidade por essas condutas. Contudo, isso apenas seria possível se ficasse comprovada a omissão do Estado responsável por processar e julgar tais crimes ou se esse Estado estivesse utilizando subterfúgios para não realizar o julgamento de maneira justa.

\section{CONSIDERAÇÕES FINAIS}

Existe uma maior organização em certos grupos terroristas, tanto em termos de hierarquia quanto em relação ao planejamento de sua atuação e aos recursos financeiros utilizados. Mesmo que ainda não exista um conceito global de terrorismo, é possível considerar que condutas terroristas são atos violadores dos direitos humanos, praticados em larga escala, para alcançar objetivos políticos por meio da pressão exercida nos governos e organizações. Como escreveu o filósofo francês Jacques 
Derrida (2004, p. 16, tradução nossa), é necessário rigor na conceituação do fenômeno, pois, como qualquer noção jurídica, "quanto mais um conceito é confuso, mais fácil se torna seu uso por oportunismo"15.

Assim, conclui-se que a ordem estabelecida dentro de grupos terroristas dessa magnitude atende aos critérios estabelecidos por Hans-Peter Kaul (apud HOLVOET, 2013, p. 8) para que eles sejam considerados sujeitos ativos de crimes contra a humanidade. Esses grupos realizam atentados que podem ser considerados ataques, generalizados ou sistemáticos, contra qualquer população civil, conforme previsto no art. $7^{\circ}$ do Estatuto de Roma.

Ressalta-se novamente que o EI não é o único grupo que atende a essa definição de organização e que, por conseguinte, pode cometer crimes contra a humanidade. Tal entendimento pode ser aplicado a outros grupos que possuem atuação similar, como a Al Qaeda e o Boko Haram. Os critérios estabelecidos por Kaul devem então ser observados para ampliar a admissão de quais organizações podem cometer crimes contra a humanidade, para evitar a impunidade. Afinal, os defensores de grupos terroristas podem argumentar que tais organizações não podem ser considerados sujeitos ativos desse crime, ainda que realizem condutas que afetam todo o conjunto da comunidade internacional e violem os direitos humanos.

Destaque-se mais uma vez que o TPI somente pode atuar como aparato complementar à jurisdição penal nacional. A jurisdição desse tribunal apenas será admissível em casos em que se verifique a incapacidade ou a falta de vontade dos Estados de processar os responsáveis. Assim, somente nessas situações e com a verificação dos critérios necessários para caracterizar uma organização terrorista como sujeito ativo de crime contra a humanidade, seria possível o julgamento de atos de terrorismo pelo referido órgão jurisdicional.

\section{REFERÊNCIAS}

ALEMANHA. Código Penal Alemão [em inglês]. Disponível em: https://bit.ly/3atGoyj. Acesso em: 1 set. 2019.

ALMEIDA, Álvaro Okura de; BAZZANO, Ariana. 11 de Setembro e o Discurso do Terror: Uma Reflexão. In: FERNANDES, Antonio Scarance; ZILLI, Marcos Alexandre Coelho (coord.).

Terrorismo e justiça penal: reflexões sobre a eficiência e o garantismo. Belo Horizonte: Fórum, 2014. p. 73-102.

15 No original: “plus un concept est confus, plus il est docile à son appropriation opportuniste”. 
ALMOND, Mark. First hooded Palestinian terrorists tortured 11 Israeli Olympic athletes in Munich... then they murdered them in an atrocity that shocked the world, writes. Daily Mail, Londres, 12 ago. 2018. Disponível em: http://dailym.ai/3kR3PWM. Acesso em: 30 abr. 2020.

AMBOS, Kai. Processando crimes internacionais em níveis nacional e internacional: justiça $\mathrm{x}$ Realpolitik. In: JAPIASSÚ, Carlos Eduardo Adriano (coord.). Direito Penal Internacional. Rio de Janeiro: Lumen Juris, 2007. p. 75.

BADIE, Bertrand. Faut-il créer un tribunal international pour juger les crimes de Daech ? La Croix, Paris, 26 mar. 2019. Disponível em: https://bit.ly/2FwuPLn. Acesso em: 15 set. 2019.

BASSIOUNI, Mahmoud Cherif. Crimes Against Humanity: Historical Evolution and Contemporary Application. 2011. Disponível em: https://bit.ly/33YFsRc. Acesso em: 20 out. 2016.

BECHARA, Fabio Ramazzini. Cooperação Jurídica Internacional e Terrorismo. In: FERNANDES, Antonio Scarance; ZILLI, Marcos Alexandre Coelho (coord.). Terrorismo e justiça penal: reflexões sobre a eficiência e o garantismo. Belo Horizonte: Fórum, 2014. p. 381-400.

BJØRGO, Tore. (ed.). Root Causes of Terrorism. Myths, reality and ways forward. London e New York: Routledge, 2005. Disponível em: https://bit.ly/3azWrdN. Acesso em: 2 ago. 2019.

BRUCE, Gregor. Definition of Terrorism. Social and Political Effects. Journal of Military and Veterans' Health, Hobart, v. 21, n. 2, maio 2013, p. 26. Disponível em: https://bit.ly/2DW3DoJ. Acesso em: 2 ago. 2019.

CALLEGARI, André Luís et al. Reflexões críticas e comentários à Lei de Terrorismo: de acordo com a Lei ${ }^{0}$ 13.260/2016. Porto Alegre: Livraria do Advogado, 2016.

DERRIDA, Jacques. Qu'est-ce que le terrorisme ? Le Monde diplomatique, Paris, fev. 2004, p. 16. Disponível em: https://bit.ly/3kONVfS. Acesso em: 2 ago. 2019.

DUBUISSON, François. La définition du "terrorisme" : débats, enjeux et fonctions dans le discours juridiques. Confluences Méditerranée, n 102, p. 29-45, 2017/3. Disponível em: https://bit.ly/3iIR5Q9. Acesso em: 2 ago. 2019.

EL DIFRAOUI, Abdelasiem. Al-Qaida par l'image. La prophétie du martyre. França: PUF, 2013.

ESPANHA. Código Penal. Disponível em: https://bit.ly/3fUuTks. Acesso em: 12 ago. 2019.

ESPANHA. Constitución Española de 1978. Disponível em: https://bit.ly/3gZkW6I. Acesso em: 11 ago. 2018.

ESSADO, Tiago Cintra. Terrorismo conforme o direito norte-americano. In: FERNANDES, Antonio Scarance; ZILLI, Marcos Alexandre Coelho (coord.). Terrorismo e justiça penal: reflexões sobre a eficiência e o garantismo. Belo Horizonte: Fórum, 2014. p. 135-166.

ESTADOS UNIDOS. Anti-terrorism Act. Dec. 22, 1987. Disponível em: https://bit.ly/344qlWc. Acesso em: 9 ago. 2019. 
EUROPOL. Terrorism Situation and Trend Report 2019 (TE-SAT). 27 jun. 2019. Disponível em: https://bit.ly/3auwI6y. Acesso em: 20 jul. 2019.

FERNANDES, Daniela. O que põe a França na mira de extremistas? BBC Brasil, São Paulo, 26 jul. 2016. Disponível em: https://bbc.in/30XoCQF. Acesso em: 11 ago. 2019.

FRANÇA. Code pénal. Disponível em: https://bit.ly/2E8fVKe. Acesso em: 12 ago. 2019.

GEMAQUE, Silvio Cesar Arouck. O Combate ao terrorismo no direito inglês: uma visão de equilíbrio entre a repressão e os Direitos Fundamentais. In: FERNANDES, Antonio Scarance; ZILLI, Marcos Alexandre Coelho (coord.). Terrorismo e justiça penal: reflexões sobre a eficiência e o garantismo. Belo Horizonte: Fórum, 2014. p. 167.

GOUVERNEMENT.FR. Le parquet national anti-terroriste est créé. 1 jul. 2019. Disponível em: https://bit.ly/30Zvkph. Acesso em: 15 set. 2019.

HOLVOET, Mathias. The State or Organisational Policy Requirement Within the Definition of Crimes Against Humanity in the Rome Statute: An Appraisal of the Emerging Jurisprudence and the Implementation Practice by ICC States Parties. 2013. Disponível em: https://bit.ly/30ZwqRZ. Acesso em: 20 ago. 2019.

JAPIASSÚ, Carlos Eduardo Adriano. O Direito Penal Internacional. Belo Horizonte: Del Rey, 2009. [Coleção Para Entender].

LAFUENTE, Alfredo Liñán. El Crimen Contra La Humanidad. Madrid: Dykinson. 2015.

LAQUEUR, Walter. Terrorism. Boston: Little Brown, 1977.

LEAGUE OF NATIONS. Convention pour la prévention et la répression du terrorisme.

Genève, 16 nov. 1937. Disponível em: https://bit.ly/3fXgyUt. Acesso em: 31 ago. 2019.

LES ATTENTATS du 13-Novembre ne sont pas un crime contre l'humanité. L'Express, Paris, 9 set. 2019. Disponível em: https://bit.ly/2PYgbhS. Acesso em: 15 set. 2019.

MALUF, Elisa Leonesi. Terrorismo e prisão cautelar: eficiência e garantismo. São Paulo: LiberArs, 2016.

MASTOR, Wanda. L'état d'exception aux Etats-Unis : le USA Patriot Act et autres violations « en règle » de la Constitution. Annuaire International de justice constitutionnelle, n. 24, Paris, 2008. p. 461-478. Disponível em: https://bit.ly/3av2qAp. Acesso em: 2 ago. 2019.

MELIÁ, Manuel Cancio. Los Delitos de Terrorismo en Derecho Penal Español. In: FERNANDES, Antonio Scarance; ZILLI, Marcos Alexandre Coelho (coord.). Terrorismo e justiça penal: reflexões sobre a eficiência e o garantismo. Belo Horizonte: Fórum, 2014. p. 183-226.

MENABE, Catherine. L’appréhension pénale du terrorisme. Civitas Europa, Nancy, n. 36, p. 171177, 2016/1. Disponível em: https://bit.ly/3kP1Fak. Acesso em: 2 ago. 2019. 
MOLINS, François. Actes de terrorisme: nouveaux crimes contre l'humanité ? Cadre du colloque “70 ans après Nuremberg - Juger le crime contre l’humanité”. Paris, 30 set. 2016. Disponível em: https://bit.ly/2FjEsN5. Acesso em: 15 set. 2019.

MORENO, Juan Damián. Especialidades Procesales del Derecho Español em Materia de Terrorismo. In: FERNANDES, Antonio Scarance; ZILLI, Marcos Alexandre Coelho (coord.). Terrorismo e justiça penal: reflexões sobre a eficiência e o garantismo. Belo Horizonte: Fórum, 2014. p. 227-242.

NAPOLEONI, Loretta. A fênix Islamista: o Estado Islâmico e a reconfiguração do Oriente Médio. Tradução Milton Chaves de Almeida. Rio de Janeiro: Bertrand Brasil, 2015.

NARANJO, José. Boko Haram liberta 82 meninas sequestradas na Nigéria há três anos. El País, Dakar, 7 maio 2017. Disponível em: https://bit.ly/2Y59C1e. Acesso em: 1 maio de 2020.

PELLETIER, Éric. Un "livre noir" fait le bilan de deux décennies de terrorisme en Europe. Le Parisien, Paris, 4 mar. 2019. Disponível em: https://bit.ly/30XvQEo. Acesso em: 2 ago. 2019.

RAPAPORT, David C. The Four Waves of Rebel Terror and September 11. Anthropoetics, [s. l.], VIII, nº 1, 2002. Disponível em: https://bit.ly/2E8LTWM. Acesso em: 19 jul. 2019.

REINARES, Fernando. Conceptualizando el terrorismo internacional. 2005. Terrorismo Internacional, n 79/2005. Disponível em: https://bit.ly/3g16U2X. Acesso em: 2 ago. 2019.

REINO UNIDO. Terrorism Act 2000. 24 jul. 2000. Disponível em: https://bit.ly/2CvCZCt. Acesso em: 12 ago. 2019.

RUIC, Gabriela. A vida dos reféns do Estado Islâmico durante o cativeiro. Exame, [s. l.], 31 out. 2014. Disponível em: https://bit.ly/3g2TG5T. Acesso em: 30 abr. 2020.

SCHMID, Alex P. (ed.). The Routledge Handbook of Terrorism Research. New York e Londres: Routledge, 2013.

SCHMID, Alex P. 50 Un- and Under-researched Topics in the Field of (Counter-) Terrorism Studies. Perspectives on Terrorism, [s. l.], v. 5, n. 1, p. 76-78, 2011. Disponível em: https://bit.ly/31OKk8A. Acesso em: 25 jul. 2019.

SCHMID, Alex P.; JONGMAN, Albert J. Political Terrorism. A New Guide to Actors, Authors, Concepts, Data Bases, Theories, \& Literature. New Brunswick: Transactions Books, 1988.

SCHMID, Alex. Terrorism - The Definitional Problem. Case Western Reserve Journal of International Law, v. 36, n. 2, p. 375-419, 2004. Disponível em: https://bit.ly/3kNSLd0. Acesso em: 22 jul. 2019.

TANGERINO, Davi de Paiva Costa. Aspectos penais do terrorismo na Alemanha: uma breve introdução. In: FERNANDES, Antonio Scarance; ZILLI, Marcos Alexandre Coelho (coord.). Terrorismo e justiça penal: reflexões sobre a eficiência e o garantismo. Belo Horizonte: Fórum, 2014. p. 273-290. 
UNITED NATIONS OFFICE ON DRUGS AND CRIME (UNODC). Manual on International Cooperation in Criminal Matters related to Terrorism. 2009. Disponível em: https://bit.ly/3atlcbr. Acesso em: 9 ago. 2019.

UNITED NATIONS. General Assembly Resolution 42/159. 7 dez. 1987. Disponível em: https://bit.ly/2E4qSfZ. Acesso em: 8 ago. 2019.

UNITED NATIONS. General Assembly Resolution 49/60. 17 feb. 1995. Disponível em: https://bit.ly/3gZq0YA. Acesso em: 8 ago. 2019.

UNITED NATIONS. General Assembly Resolution 51/210. 16 jan. 1997. Disponível em: https://bit.ly/3atP33y. Acesso em: 9 ago. 2019.

UNITED NATIONS. International Convention Against the Taking of Hostages. 17 Dec. 1979. Disponível em: https://bit.ly/3iOQJYf. Acesso em: 21 ago. 2019.

UNITED NATIONS. International Convention for the Suppression of Acts of Nuclear Terrorism. 13 abr. 2005. Disponível em: https://bit.ly/343ELWT. Acesso em: 9 ago. 2019.

UNITED NATIONS. International Residual Mechanism for Criminal Tribunals. Legacy website of the International Criminal Tribunal for Rwanda. 24 jul. 2018. Disponível em: https://bit.ly/3427E5w. Acesso em: 1 set. 2019.

UNITED NATIONS. Report of the International Law Commission on the work of its sixtyfifth session. 3 abr. 2019. Disponível em: https://bit.ly/3kNxLmP. Acesso em: 4 ago. 2019.

UNITED STATES DEPARTMENT OF STATE. Country Reports on Terrorism 2017. 19 set. 2018. Disponível em: https://bit.ly/2Y42jqJ. Acesso em: 20 jul. 2019.

ZILLI, Marcos Alexandre Coelho. O Tribunal Penal Internacional: Jurisdição Permanente para os Crimes Internacionais. In: FERNANDES, Antonio Scarance; ZILLI, Marcos Alexandre Coelho (coord.). Direito Processual Penal Internacional. São Paulo: Atlas, 2013. p. 155-193. 